\title{
Research Paper Growth in area, production and yield of major crops in Rajasthan
}

See end of the paper for authors' affiliations

Correspondence to : Jitendra Suman

Department of Agricultural Economics, S.K.N College of Agriculture, S.K.N. Agriculture University, Jobner (Rajasthan) India

Paper History :

Received : 21.05.2019;

Revised : 17.07.2019;

Accepted : 21.08.2019
ABSTRACT : The effect of area and yield on the production of major crops of the state was assessed by compound growth rates of area, production and productivity. The growth in production of cereals recorded positive and significant at 1 per cent level of significance at the rate of 4.00 per cent per annum largely due to positive and significant at 5 per cent level of significance growth in productivity by 2.70 per cent per annum. The growth in production of pulses recorded positive and non-significant at the rate of 2.19 per cent per annum it is also positive and non-significant growth in productivity by 1.77 per cent whereas growth in area increased by 0.79 per cent per annum which is positive and nonsignificant. Oilseeds were recorded positive and significant at 1 per cent level of significance at the rate of 2.03, 4.29 and 3.08 per cent per annum, respectively growth in area, production and productivity. The productivity of cash crops recorded positive and significant at 1 per cent level of significance with annual growth at the rate of 3.29 per cent which is attributable by significant at 5 per cent level of significance growth in area by 5.03 per cent per annum. The production of spices recorded a positive and significant at 1 per cent level of significance annual growth at the rate of 4.14 per cent which was largely attributable by significant at 1 per cent level of significance growth in area by 3.64 per cent per annum with 1.07 per cent positive and significant growth of productivity.

KEY WORDS : Area, Production, Productivity, Compound growth

How To Cite This PAPer : Suman, Jitendra, Singh, Hari and Verma, Devendra Kumar (2019). Growth in area, production and yield of major crops in Rajasthan. Internat. Res. J. Agric. Eco. \& Stat., 10 (2) : 278-284, DOI : 10.15740/HAS/IRJAES/10.2/278-284. Copyright@ 2019: Hind Agri-Horticultural Society. 